\title{
The anti-inflammatory effect of hydrogen sulphide on acute necrotizing pancreatitis in rats
}

\author{
Kutay Sağlam¹, Etem Alhan¹, Serdar Türkyılmaz¹, Birgül Kural Vanizor², Cengiz Erçin³
}

\section{ABSTRACT}

Cite this paper as: Sağlam K, Alhan E, Türkyılmaz S, Kural Vanizor B, Erçin C. The anti-inflammatory effect of hydrogen sulphide on acute necrotizing pancreatitis in rats. Turk J Surg 2017; 33: 158-163.

This study was presented at the $19^{\text {th }}$ National Congress of Surgery, 16-20 April 2014, Antalya, Turkey.

'Department of General Surgery, Karadeniz Technical University School of Medicine, Trabzon, Turkey

2Department of Medical Biochemistry, Karadeniz Technical University School of Medicine, Trabzon, Turkey ${ }^{3}$ Department of Pathology, Kocaeli University School of Medicine, Kocaeli, Turkey

Address for Correspondence Kutay Sağlam e-mail:saglamk@gmail.com

Received: 18.06.2016 Accepted: 04.09.2016

\section{CCopyright 2017} by Turkish Surgical Association
Objective: The aim of this study was to investigate the dose-dependent anti-inflammatory effectof the Hydrogen sulfidedonor sodiumhydrosulphide on acute necrotizing pancreatitis in rats.

Material and Methods: A total of 42 male Sprague-Dawley rats were divided into 4 groups: sham+saline (group 1), sham+NaHS (group 2), acute necrotizing pancreatitis+saline (group 3), and acute necrotizing pancreatitis+NaHS (group 4). Acute pancreatitis was induced in rats in groups 3 and 4 with the infusion of glycodeoxycholic acidinto the biliopancreatic canal and infusion of cerulein parenterally. In group $4,10 \mathrm{mg} / \mathrm{kg}$ NaHS was administered intraperitoneally after cerulein infusion. Tests for liver and kidney function, interleukin-6, lactate dehydrogenase in bronchoalveolar lavage, and malonyaldehyde and myeloperoxidase activities in pancreas and lung tissue were performed, and histopathologic examination of pancreas was conducted.

Results: In groups 3, a significant increase in amylase, alanine aminotransferase, urea, interleukine-6, lungmalondialdehydeand myeloperoxidase activities, pancreas myeloperoxidase activity, edema, and necrosis in pancreas tissue and a significant decrease in serum calcium levels were detected $(p<0.05)$. In group 4 , addition of NaHS resulted in a significant decrease in lactate dehydrogenase level in bronchoalveolar lavage, amount of urea, lung myeloperoxidase activity, and pancreatic edema $(\boldsymbol{p}<0.05)$.

Conclusion: Although not in pancreatic necrosis, hydrogen sulphide has an anti-inflammatory effect especially in the inflammatory process in lung and edema in pancreasin acute necrotizing pancreatitis at particular doses. With further studies evaluating the anti-inflammatory effects of hydrogen sulphide, we believe it can be used in the treatment of edematous acute pancreatitis and the related complications in lungs.

Keywords: Hydrogen sulphide, pancreatitis, rats

\section{INTRODUCTION}

Acute pancreatitis is an inflammatory disorder of the pancreas presenting with abdominal pain and elevated pancreatic enzymes in the blood (1).Gall bladder stones and chronic alcohol usage are the etiologic factors in $80 \%$ to $90 \%$ of the cases (2). The incidence of pancreatitis ranges from 4.9 to 35 per 100.000. Mortality rates were previously reported $10 \%$ to $30 \%$. In necrotizing pancreatitis, mortality rates are reported to increase up to $12 \%$ in the case of sterile necrosis, to $30 \%$ in infected necrosis, and to $47 \%$ in multi-organ failurein previous studies $(3,4)$.

The pathophysiology of acute pancreatitis is not obvious, although intracellular activation of the digestive enzymes in acinar cells is accepted as the starting point. Free oxygen radicals released from the injured cells and mediators and cytokines from the leukocytes play a major role in the progression of acute pancreatitis and multi-organ failure (5). Autodigestion of pancreas and failure of microcirculation in pancreas are the main mechanisms in the pathophysiology of pancreatitis (6). Acute necrotizing pancreatitis (ANP) is the most severe form of inflammation in pancreas. Coagulation necrosis of the glandular cells and fat tissue are the pathological findings in ANP.

Hydrogen sulphide $\left(\mathrm{H}_{2} \mathrm{~S}\right)$ is a gaseous mediator, which can be endogenously synthesized by cystathionine$\delta$-lyase (CSE) and cystathionine- $\beta$-synthase (CBS) enzymes from L-cysteine aminoacids $(7,8)$. The synthesis of $\mathrm{H}_{2} \mathrm{~S}$ is increased in disorders coursing with inflammation like acute pancreatitis, sepsis, and endotoxemia (9). The effects of $\mathrm{H}_{2} \mathrm{~S}$ on inflammation are conflicting. Inhibition of endogenously synthesized $\mathrm{H}_{2} \mathrm{~S}$ has previously shown to decrease the inflammatory response $(10,11)$. With these properties, $\mathrm{H}_{2} \mathrm{~S}$ was thought to be a pro-inflammatory molecule. The anti-inflammatory property of $\mathrm{H}_{2} \mathrm{~S}$ was detected in a study conducted with an $\mathrm{H}_{2}$ S-releasing non-steroidal anti-inflammatory drug (NSAID) (diclofenac) when $\mathrm{H}_{2} \mathrm{~S}$ provided a more anti-inflammatory response compared with an $\mathrm{H}_{2} \mathrm{~S}$ non-releasing NSAID (12).

Sidhapuriwala et al. (13) showed the anti-inflammatory effect of $\mathrm{H}_{2} \mathrm{~S}$ in edematous pancreatitisin their study using $\mathrm{H}_{2} \mathrm{~S}$-releasing $\mathrm{S}$-diclofenac. The anti-inflammatory effect of $\mathrm{H}_{2} \mathrm{~S}$ was also shown 
by the inhibition of TNF-a vs. IL-6 in the study of Xu et al. (14) with hemorrhagic shock-induced rats. $\mathrm{H}_{2} \mathrm{~S}$ inhibits the nuclear factor $\kappa \beta$ (NF-k $\beta$ ), one of the main regulators of inflammation, and decreases proinflammatory cytokines, chemokines, and adhesion molecules (15-17). Further, its antioxidant and anti-apoptotic efficiency have been previously reported (18-20). To the best of our knowledge, no study has evaluated the anti-inflammatory effect of $\mathrm{H}_{2} \mathrm{~S}$ in necrotizing pancreatitis.

The aim of this study was to investigate the dose-dependent anti-inflammatory effects of $\mathrm{H}_{2} \mathrm{~S}$ on the histopathology of pancreas and its functions by biochemical parameters in necrotizing pancreatitis in rats.

\section{MATERIAL AND METHODS}

This experimental study was conducted with the approval of Ethical Committee of the Surgical Research Laboratory of our hospital.

Forty-two male Sprague-Dawley rats weighing 300-350 g were used in the study. Rats were maintained in routine laboratory conditions, $21^{\circ} \mathrm{C}, 60 \%$ to $70 \%$ humidity, and $12 / 12 \mathrm{~h} \mathrm{light/ \text {dark }}$ cycle, at our institution'sAnimal Research Laboratory. Rats were divided into four groups. Oral intake was restrictedto water $12 \mathrm{~h}$ before the operation. Anesthesia was administered with intraperitoneal $50 \mathrm{mg} / \mathrm{kg}$ ketamine (Ketalar, Eczacıbaşı) injection. Subsequently, the right internal jugular veins of the rats were catheterized for fluid replacement, and left carotid artery was catheterized for blood sampling.

Group 1 (Sham+saline, $\mathrm{n}=7$ ): Right jugular vein and carotid artery catheterizationwas performed. Physiologic saline was infused at $8 \mathrm{~mL} / \mathrm{kg}$ per hour for $24 \mathrm{~h}$ via the right jugular venous catheter.

Group 2 (Sham $+\mathrm{H}_{2} \mathrm{~S}, \mathrm{n}=7$ ): Procedures performed for group 1 were performed and then $10 \mathrm{mg} / \mathrm{kg}$ sodium hydrosulphide (NAHS) (Sigma-Aldrich) (Lot No: 06396APV) dissolved in distilled water was administrated intraperitoneally.

Group 3 (ANP+saline, $n=15$ ): After jugular vein catheterization, the distal end of thecatheter was placed in the suprascapular region in 15 rats in this group. Subsequently, laparotomy was performed. Bilio-pancreatic duct was catheterized by a transduodenal approach from the antimesenteric sideof the duodenum. Pancreatic fluid was drained with the help of gravity for $5 \mathrm{~min}$. Main hepatic duct was clamped. Then 10-mMol glycodeoxycholic acid (GDOC, Sigma St Louis, 3528) $1.2 \mathrm{~mL} / \mathrm{kg}$ under $30 \mathrm{mmHgpressure} \mathrm{was} \mathrm{infused} \mathrm{via} \mathrm{the}$ catheter. This pressure was achieved using a volume-controlled infusion pump (IVAC 7000; United Kingdom Hampshire, Alaris Medical Systems, RG22, 4BS). After infusion, the catheter was removed and the duodenal hole was repaired. Subsequently, cerulein (Sigma \& Aldrich Chemie, $\mathrm{GmbH}$, C-9026) was infused for $6 \mathrm{~h}, 5 \mu \mathrm{g} / \mathrm{kg}$ per hour, with the infusion pump. Following this, serum physiologic was infused at a rate of $8 \mathrm{~mL} / \mathrm{kg} / \mathrm{h}$ for $18 \mathrm{~h}$.

Group 4 ( $\mathrm{ANPH}_{2} \mathrm{~S}, \mathrm{n}=13$ ): Like group 3, after acute pancreatitis was formed, $8 \mathrm{~mL} / \mathrm{kg} / \mathrm{h}$ serum physiologic and $5 \mu \mathrm{g} / \mathrm{kg}$ cerulein was infused; $8 \mathrm{~mL} / \mathrm{kg}$ Ringer's lactate was infused for the remaining $18 \mathrm{~h}$. After cerulein infusion, $10 \mathrm{mg} / \mathrm{kg} \mathrm{NaHS}$ was applied to the rats intraperitoneally.

After $24 \mathrm{~h}$, blood samples were collected from the rats for analyzing biochemical parameters and serum IL-6 levels. Blood samples were centrifuged in Eppendorf Centrifuge 5810 machine at $3200 \mathrm{rpm}$ for $10 \mathrm{~min}$ for analyzing biochemical parameters. Enzymatic colorimetric analysis of serum samples was conducted for measuring amylase, glucose, urea, creatinine, ALT, and calcium levels using COBAS 6000 machine. Enzyme linked-immunosorbent assay (ELISA) Kit, RayBio ${ }^{\circledR}$ Rat IL-6 (Lot No: 1137545A), was used for measuring IL-6 levels in serum samples. Then thorax was opened by sternotomy. The left lung was clamped from the left main bronchus and a cannula was placed in the trachea. Bronchoalveolar lavage was performed with $2 \mathrm{cc}$ phosphate buffered saline (PBS) solution. Lavage fluid was stored at $-20^{\circ} \mathrm{C}$ in tubes containing EDTA for protein measurement. At the end of the experiment, BAL protein levels were measured by Lowry method (21). COBAS 6000 machine was used for BAL LDH measurement. After this step, pneumonectomy was performed for the left lung, and the extracted tissue freezed in liquid nitrogen for malondialdehyde (MDA) and myeloperoxidase (MPO) measurements.

After all these procedures, laparotomy was performed and the pancreaswas extracted. Previously defined steps performed for the lung were repeated the measurement of MPO and MDA in the pancreas. Part of the pancreas was stored in $10 \%$ formaldehyde-containing tubes for histological examination. Tissue analysis in the pancreas and lungwere performed with the method described by Uchiyama and Mihara, by measuring MDA concentration with thyobarbituric acid colorimetric reaction (22). MPO activity was analyzed as described by Bradley et al. (23).

Pathological studies were conducted on slides prepared from pancreas of the rats. Tissue samples were fixed in 10\% formaldehyde. The slides were studied under a light microscope to observe necrosis, edema, and granulocyte infiltration. All these pathological changes were histologically evaluated by the same pathologist (Table 1) (24).

\section{Statistical Analyses}

For data analyses Statistical Package for the Social Sciences 13.0 (SPSS Inc.; Chicago, IL, USA) was used. Descriptive statistics were summarized with mean and standarderror. Numeric data appropriate for normal distribution were evaluated with Student $t$ test, and those not appropriate for normal distribution were evaluated with Mann-Whitney U test. Appropriateness of normal distribution was evaluated with KolmogorovSmirnov test. $\mathrm{P}<0.05$ was accepted as statistically significant.

\section{RESULTS}

Sham+saline and sham $+\mathrm{H}_{2} \mathrm{~S}$ groups had no mortality. Four rats in Sham+ANP group and two rats in $\mathrm{ANP}+\mathrm{H}_{2} \mathrm{~S}$ group died (mortality rates $26.6 \%$ and $15.2 \%$, respectively). There was a statistically significant difference in 24-h serum glucose, urea, amylase, creatinine, ALT, calcium, and IL- 6 levels and hourly urine flow levels between the groups with ANP and those without. $\mathrm{H}_{2} \mathrm{~S}$ application significantly improved urea and $\mathrm{BAL}$ $\mathrm{LDH}$ values. Statistical comparison of the groups and significance values are given in Table 2 . 
Table 1. Histopathological scoring criteria for necrotizing pancreatitis

\begin{tabular}{|ll|}
\hline Score & Description \\
\hline Edema & \\
\hline 0 & Absent \\
\hline 0.5 & Focal expansion of interlobar septae \\
\hline 1 & Diffuse expansion of interlobar septae \\
\hline 1.5 & Same as $1+$ focal expansion of interlobal septae \\
\hline 2 & Same as $1+$ diffuse expansion of interlobar septae \\
\hline 2.5 & Same as $2+$ focal expansion of interacinar septae \\
\hline 3 & Same as $2+$ diffuse expansion of interacinar septae \\
\hline 3.5 & Same as $3+$ focal expansion + intercellular spaces \\
\hline 4 & Same as $3+$ diffuse expansion + intercellular spaces \\
\hline
\end{tabular}

$\begin{array}{ll}\text { Acinar necrosis } \\ 0 & \text { Absent }\end{array}$

\begin{tabular}{|c|c|}
\hline 0 & Absent \\
\hline 0.5 & Focal occurrence of $1 Y 4$ necrotic cells/high power field \\
\hline 1 & Diffuse occurrence of $1 Y 4$ necrotic cells/high power field \\
\hline 1.5 & $\begin{array}{l}\text { Same as } 1+\text { focal occurrence of } 5 \text { Y } 10 \text { necrotic cells/high } \\
\text { power field }\end{array}$ \\
\hline 2 & $\begin{array}{l}\text { Diffuse occurrence of } 11 Y 16 \text { necrotic cells/high power } \\
\text { field }\end{array}$ \\
\hline 2.5 & $\begin{array}{l}\text { Same as } 2+\text { focal occurrence of } 11 Y 16 \text { necrotic cells/high } \\
\text { power- field }\end{array}$ \\
\hline
\end{tabular}

3 Diffuse occurrence of $11 Y 16$ necrotic cells/high power field

3.5 Same as $3+$ focal occurrence of $>16$ cells/high power-
field

4> Necrotic cells/high power field (Extensive confluent necrosis)

\begin{tabular}{|l|l|}
\hline Inflammation and perivascular infiltrate \\
\hline $0,0-1$ & Intralobular or perivascular leukocytes/high power field \\
\hline $0.5,2 \mathrm{Y} 5$ & Intralobular or perivascular leukocytes/high power field \\
\hline $1,6 \mathrm{Y} 10$ & Intralobular or perivascular leukocytes/high power field \\
\hline $1.5,11 Y 15$ & Intralobular or perivascular leukocytes/high power field \\
\hline $2,16 Y 20$ & Intralobular or perivascular leukocytes/high power field \\
\hline $2.5,21 Y 25$ & Intralobular or perivascular leukocytes/high power field \\
\hline $3,26 Y 30$ & Intralobular or perivascular leukocytes/high power field \\
\hline $3.5,>30$ & Leukocytes/high power field or focal microabscesses \\
\hline $4,>35$ & Leukocytes/high power field or confluent \\
\hline
\end{tabular}

Malondialdehyde and MPA were measured in pancreas and lung to detect the oxidative injury and to detect the neutrophil infiltration, respectively. MDA and MPO in lung and MPO in pancreas were significantly increased in the groups with pancreatitis, and $\mathrm{H}_{2} \mathrm{~S}$ application was found to decrease lung MPO. Statistical comparison of the groups and significance values are given in Table 3.

On histological examination, edema, necrosis, and cellular infiltration were significantly increased in the groups with pancreatitis. The effect of $\mathrm{H}_{2} \mathrm{~S}$ application on the decrease of edema was statistically significant. Statistical comparison of the groups and significance values are given in Table 4.

\section{DISCUSSION}

In the present study, NaHS decreases mortality, does not have any effect on pancreatic necrosis, improves the organ functions, and has partial anti-inflammatory effects with regard to pancreatitis in ANP.

Different experimental acute pancreatitis models have been defined previously. In the present study, the method of Schmidt et al. (24) for ANP was used. In this pancreatitis modelconstructed using cerulein and glycodeoxycholic acid,elevated pancreatic enzymes, edema of pancreatic tissue, and acinar cell necrosis were observed. This method is the most widely used, safest, and standardized method. Patients usually present to the outpatient clinic 24 to $36 \mathrm{~h}$ after the onset of pancreatitis. Therefore, $\mathrm{H}_{2} \mathrm{~S}$ was given $6 \mathrm{~h}$ after the induction of the experiment.

$\mathrm{H}_{2} \mathrm{~S}$ is a gaseous mediator, which can be endogenously synthesized. $\mathrm{H}_{2} \mathrm{~S}$ opens the adenosine triphosphate (ATP)-dependent potassium $\left(\mathrm{K}^{+}\right)$channels and relaxes the blood vessels and smooth muscles in the gastrointestinal system. $\mathrm{H}_{2} \mathrm{~S}$ has a vasodilatory effect $(25,26)$.

Inhibitionof endogenous $\mathrm{H}_{2} \mathrm{~S}$ using $\mathrm{CSE}$ inhibitors decreases the inflammatory response, showing the proinflammatory effect of $\mathrm{H}_{2} \mathrm{~S}(18,27)$. However, in this study, the anti-inflammatory effect of $\mathrm{H}_{2} \mathrm{~S}$ was observed by comparing the effects of $\mathrm{H}_{2} \mathrm{~S}$-releasing NSAID (diclophenac) and $\mathrm{H}_{2} \mathrm{~S}$-non-releasing NSAID (14). $\mathrm{H}_{2} \mathrm{~S}$-releasing drugs were shown to have anti-inflammatory effects (28). In the study of Sidhapuriwala et al. (29) investigating the anti-inflammatory effect of $\mathrm{H}_{2} \mathrm{~S}$ using $\mathrm{NaHS}$, an $\mathrm{H}_{2} \mathrm{~S}$ donor, at $10 \mathrm{mg} / \mathrm{kg}$, a decrease in the inflammation in pancreas and lungs secondary to edematous pancreatitis was observed. The aim of the present study was to evaluate the efficiency of the same dose in necrotizing pancreatitis in rats.

Pancreatic necrosis is the key point in severe pancreatitis and directly correlates with mortality (30). Histological examination is important in detecting the severity of acutepancreatitis. In the present study, edema, acinar necrosis, hemorrhage, fat necrosis, and inflammation in pancreas was evaluated according to the histopathological scoring scale defined by Lowry et al. (21). We found that edema, perivascular infiltration, and necrosis in the pancreatitis group were significantly higher than those in the non-pancreatitis group $(p<0.05)$. In the group with NaHS (group 4), edema significantly decreased ( $p<0.05$ ). $\mathrm{H}_{2} \mathrm{~S}$ had no effects on pancreatic necrosis. The other factor increasing necrosis is apoptosis (31). In the present study, we did not work on apoptosis. Xu DQ et al. (14) showed the antiapoptotic property of $\mathrm{H}_{2} \mathrm{~S}$ in their study.

In the present study, the enzyme activity of the lipid peroxidation product MDA was measured to detect the oxidative stress in pancreas and lung tissue due to pancreatitis and that of MPO was measured to detect neutrophil infiltration. Pancreatitis groups showed MDA and MPO increase in pancreatic tissue. Increase in MPO levels was statistically significant $(p<0.05)$. MDA and MPO decreased in the group containing 
Table 2. Glucose, amylase, ALT, urea, creatinine, calcium levels in serum and LDH and urine levels in BAL in the $24^{\text {th }}$ hour

\begin{tabular}{|c|c|c|c|c|}
\hline & Sham+saline $(n=7)$ & Sham $+\mathrm{H}_{2} \mathrm{~S}(\mathrm{n}=7)$ & ANP+saline $(n=11)$ & $A N P+H_{2} S(n=11)$ \\
\hline Amilase (U/L) & $2328 \pm 49$ & $2051 \pm 115$ & $10741 \pm 2162^{*}$ & $7849 \pm 1334$ \\
\hline Glucose (mg \%) & $239 \pm 21$ & $149 \pm 10$ & $101 \pm 9^{*}$ & $122 \pm 10$ \\
\hline Urea (mg \%) & $16 \pm 1$ & $13 \pm 1.2$ & $39 \pm 5^{*}$ & $19 \pm 5^{\#}$ \\
\hline Creatinine (mg \%) & $0.38 \pm 0.1$ & $0.44 \pm 0.4$ & $0.34 \pm 0.5$ & $0.28 \pm 0.5$ \\
\hline ALT (U/dL) & $63 \pm 3$ & $66 \pm 10$ & $247 \pm 60^{*}$ & $205 \pm 55$ \\
\hline Calcium (mg \%) & $10 \pm 0.3$ & $9.1 \pm 0.6$ & $8.2 \pm 0.2^{*}$ & $8.5 \pm 0.12$ \\
\hline BAL LDH (U/dL) & $368 \pm 58$ & $188 \pm 25$ & $590 \pm 78$ & $229 \pm 34^{\#}$ \\
\hline IL-6 & $41.2 \pm 1.4$ & $157 \pm 56$ & $995 \pm 419^{*}$ & $1248 \pm 467$ \\
\hline Urine (mL/hour) & $1.05 \pm 0.5$ & $0.7 \pm 0.2$ & $0.28 \pm 0.5^{*}$ & $0.4 \pm 0.3$ \\
\hline
\end{tabular}

Data are shown as mean \pm standard error of mean. ${ }^{*} \mathrm{p}<0.05$ : comparision of ANP and non-ANP groups; \#p<0.05: comparision of ANP+saline and ANP+H2S; ALT: alanine amino transpherase; BAL: bronchoalveolar lavage; LDH: lactate dehydrogenase; IL-6: interleukine-6; SEM: standart error

Table 3. MPO and MDA measurements in lung and pancreas tissue

\begin{tabular}{|c|c|c|c|c|}
\hline & Sham+saline $(n=7)$ & Sham $+\mathrm{H}_{2} \mathrm{~S}(n=7)$ & ANP+saline $(n=11)$ & $\mathrm{ANP}+\mathrm{H}_{2} \mathrm{~S}(\mathrm{n}=11)$ \\
\hline Lung MPO (U/mg protein) & $3.8 \pm 0.11$ & $3.7 \pm 0.76$ & $5.94 \pm 0.61^{*}$ & $4.3 \pm 0.27 \#$ \\
\hline Lung MDA (nmoL/mgProtein) & $1.00 \pm .004$ & $0.74 \pm 0.03$ & $1.47 \pm 0.14^{*}$ & $1.1 \pm 0.08$ \\
\hline Pancreas MPO (U/mg Protein) & $1.02 \pm 0.14$ & $0.82 \pm 0.15$ & $1.89 \pm 0.37^{*}$ & $1.53 \pm 0.26$ \\
\hline Pancreas MDA (nmoL/mg protein) & $0.38 \pm 0.07$ & $1.6 \pm 0.44$ & $0.7 \pm 0.14$ & $0.69 \pm 0.15$ \\
\hline \multicolumn{5}{|c|}{$\begin{array}{l}\text { Data are shown as mean } \pm \text { standard error of mean. }{ }^{*} p<0.05 \text { : comparision of ANP and non-ANP groups; }{ }^{*} p<0.05: \text { comparision of ANP }+ \text { saline and } A N P+H_{2} S \text {; } \\
\text { MPO: myeloperoxidase; MDA: malonylaldehyde }\end{array}$} \\
\hline & Sham+saline $(n=7)$ & Sham $+\mathrm{H}_{2} \mathrm{~S}(n=7)$ & ANP+saline $(n=11)$ & $\mathrm{ANP}+\mathrm{H}_{2} \mathrm{~S}(\mathrm{n}=11)$ \\
\hline Edema & $0.4 \pm 0.17$ & $0.42 \pm 0.1$ & $1.4 \pm 0.17^{*}$ & $0.8 \pm 0.15^{\#}$ \\
\hline Necrosis & $0.0 \pm 0.0$ & $0.7 \pm 0.7$ & $1.5 \pm 0.21^{*}$ & $1.7 \pm 0.45$ \\
\hline Inflammation & $0.7 \pm 0.07$ & $0.7 \pm 0.7$ & $1.1 \pm 0.1^{*}$ & $1.5 \pm 0.26$ \\
\hline
\end{tabular}

Data are shown as mean \pm standard error of mean. ${ }^{*} \mathrm{p}<0.05$ : comparision of ANP and non-ANP groups, " $\mathrm{p}<0.05$ : comparision of ANP+saline and ANP+H $\mathrm{S}$

NaHS, but this was not statistically significant. Sidhapuriwala et al. (29) showed in their study with mice that $\mathrm{H}_{2} \mathrm{~S}$ decreases pancreatic MPO activity.

Platelet activating factor, TNF- $a$, IL-1, IL- 6 , and IL- 8 are the major cytokines that have a role in pancreatic injury and are the starters of systemic anti-inflammatory response syndrome. In the present study, we used IL- 6 to detect the cytokinerole in inflammatory response. The groups with pancreatitis showed statistically significant increase in IL- 6 levels $(p<0.05)$. NaHS addition did not show any decrease in IL-6 levels. However, Xu et al. (14) showed that $\mathrm{H}_{2} \mathrm{~S}$ inhibits TNF- $\alpha$ and IL- 6 in their study.

Serum amylase increases in acute pancreatitis. Serum amylase levels are not relevant for severity of pancreatitis, and it is only used in diagnosis (32). In the present study, serum amylase levels in ANP-induced rats at $24 \mathrm{~h}$ were increased significantly $(p<0.05)$. Although not reaching a statistical significance, addition of NaHS decreased the amylase levels. Sidhapuriwala et al. (29) showed that $10 \mathrm{~mL} / \mathrm{kg}$ dose of $\mathrm{NaHS}$ decreased serum amylase levels in their studyon edematous pancreatitis.
In the present study, serum glucose levels were significantly increased in the pancreatitis groups $(p<0.05)$, but the effect of NaHS on glucose levels was not significant.

Parameters showing multi-organ injury such as serum urea and ALT levels significantly increased in the pancreatitis groups, whereas serum $\mathrm{Ca}^{++}$and urine flow significantly decreased $(p<0.05)$. These parameters were improved in NaHSadministered group. The improvement in urea was statistically significant $(p<0.05)$.

The most common and severe complications of acute pancreatitis are in the respiratory system. Hypoxemia secondary to ventilation/perfusion failure, atelectasis, pleural effusion, lung edema, and acute respiratory distress syndrome (ARDS) are some of the complications $(33,34)$. The most dangerous complication is ARDS with morality rates of approximately $50 \%$. Coagulopathies in microcirculation, lipase and phospholipase activities; and arteriovenous shunts opened by the release of kinines are the triggering factors leading to the development of ARDS (33). In the present study, LDH in BAL fluid and MDH 
and MPO in lung tissue were analyzed to evaluate lung complications. BAL LDH was used to detect lung and lung endothelial injury $(35,36)$. BAL LDH levels were elevated in pancreatitis groups. $\mathrm{H}_{2} \mathrm{~S}$ addition was shown to decrease BAL LDH values significantly $(p<0.05)$. In groups with pancreatitis, lung MDA and MPO values were significantly increased in non-pancreatitis groups $(p<0.05)$. In the groupswith $\mathrm{H}_{2} \mathrm{~S}$, lung MPO values were significantly decreased $(p<0.05)$, although changes in MDA levels were not statistically significant. Previous studies showed that $\mathrm{H}_{2} \mathrm{~S}$ prevents lung injury induced by lipopolysaccharides $(14,37) . \mathrm{H}_{2} \mathrm{~S}$ was shown to decrease the number of free oxygen radicals in rabbits with lung transplantation (38).

Xu et al. (14) Showed that $\mathrm{H}_{2} \mathrm{~S}$ prevents lung injury, inhibits apoptosis and decreases inflammatory response in hemorrhagic shock-induced rats. Also, in a study by Liu et al. (39) it was reported that $\mathrm{H}_{2} \mathrm{~S}$ inhibits Fas pathway and has preventive effectsin acute lung injury-induced rats. In a study by Sidhapuriwala et al. (29) $\mathrm{H}_{2} \mathrm{~S}$ was shown to reduce lung MPO activity, pulmonary chemokines, and adhesion molecules.

\section{Limitations}

The present study had some limitations. Anti-inflammatory effects of $\mathrm{H}_{2} \mathrm{~S}$ are dose dependent and we only used $10 \mathrm{mg} /$ $\mathrm{kg}$. Studying a wider range of dose levels may providemore information about the effects of $\mathrm{H}_{2} \mathrm{~S}$. Also, the effects of $\mathrm{H}_{2} \mathrm{~S}$ on inflammatory pathways of the other mediators except IL-6 were not evaluated.

\section{CONCLUSION}

In conclusion, autolysis of pancreas secondary to intraacinar enzyme activation is the most accepted theory in the pathogenesis of pancreatitis. Activation of leucocytes, released cytokines, and free oxygen radicals, resulting in multi-organ failure, is an important factor in pancreatitis progression. In the present study, we aimed to detect the dose-dependent effects of $\mathrm{H}_{2} \mathrm{~S}$ on rats with ANP. Although $\mathrm{H}_{2} \mathrm{~S}$ does have any effects on pancreatic necrosis, it decreases the mortality rates and improves organ functions. These are the dose-dependent partial anti-inflammatory effects of $\mathrm{H}_{2} \mathrm{~S}$.

Ethics Committee Approval: Ethics committee approval was received for this study from the ethics committee of Karadeniz Technical University (05.05.2011-2011/14).

Informed Consent: Not required in this study.

Peer-review: Externally peer-reviewed.

Author Contributions: Concept - K.S., E.A., S.T.; Design - K.S., E.A., S.T.; Analysis and/or Interpretation - B.K.V., C.E.; Literature Search - K.S.; Writing Manuscript - K.S., E.A.; Critical Reviews - K.S., E.A., S.T.

Conflict of Interest: No conflict of interest was declared by the authors.

Financial Disclosure: The authors declared that this study has received no financial support.

\section{REFERENCES}

2. Fisher WE, Andersen DK, Bell RH Jr, Saluja AK, Brunicardi FC. In: Brunicardi FC, et al. (eds) Schwartz's principles of surgery. 9th ed. McGraw - Hill; 2010. p. 1167-1186.

3. Gloor B, Müller CA, Worni M, Martignoni ME, Uhl W, Büchler MW. Late mortality in patients with severe acute pancreatitis. Br J Surg 2001; 88: 975-979. [CrossRef]

4. Warshaw AL. Pancreatic necrosis: to debride or not to debridethat is the question. Ann Surg 2000; 232: 627-629. [CrossRef]

5. Saluja AK, Steer MLP6. Pathophysiology of pancreatitis: role of cytokines and other mediators of inflammation. Digestion 1999; 60: 27-33. [CrossRef]

6. Alhan E, Küçüktülü U, Erçin C, Deger O, Cicek R. The effects of dopexamine on acute necrotizing pancreatitis in rats. Eur J Surg 2001; 167: 761-766. [CrossRef]

7. Abe K, Kimura H. The possible role of hydrogen sulfide as an endogenous neuromodulator. J Neurosci 1996; 16: 1066-1071.

8. Geng B, Yang J, Qi Y, Zhao J, Pang Y, Du J et al. H2S generated by heart in rat and its effects on cardiac function, Biochem Biophys Res Commun 2004; 313: 362-368. [CrossRef]

9. Tamizhselvi R, Koh YH, Sun J, Zhang H, Bhatia M. Hydrogen sulfide induces ICAM-1 expression and neutrophil adhesion to caerulein-treated pancreatic acinar cells through NF-kappaB and Src-family kinases pathway. Exp Cell Res 2010; 316: 1625-1636. [CrossRef]

10. Bhatia M, Wong FL, Fu D, Lau HY, Moochhala SM, Moore PK. Role of hydrogen sulfide in acute pancreatitis and associated lung injury. FASEB J 2005; 19: 623-625. [CrossRef]

11. Bhatia M, Sidhapuriwala J, Moochhala SM, Moore PK. Hydrogen sulfide is a mediator of carrageenan-induced hindpaw edema in the rat. Br J Pharmacol 2005; 145: 141-144. [CrossRef]

12. Bhatia M, Sidhapuriwala J, Sparatore A, Moore PK. Treatment with $\mathrm{H} 2 \mathrm{~S}$-releasing derivative of diclofenac reduces inflammation in carageenan-induced hindpaw oedema. Inflamm Res 2005; 185.

13. Sidhapuriwala J, Li L, Sparatore A, Bhatia M, Moore PK. Effect of Sdiclofenac, a novel hydrogen sulfide releasing derivative, on carrageenan-induced hindpaw oedema formation in the rat. Eur J Pharmacol 2007; 569: 149-154. [CrossRef]

14. Xu DQ, Gao C, Niu W, Li Y, Wang YX, Gao CJ, Ding Q, et al. Sodium hydrosulfide alleviates lung inflammation and cell apoptosis following resuscitated hemorrhagic shock in rats. Acta Pharmacol Sin. 2013; 34: 1515-1525. [CrossRef]

15. Li L, Rossoni G, Sparatore A, Lee LC, Del Soldato P, Moore PK. Antiinflammatory and gastrointestinal effects of a novel diclofenac derivative. Free Radic Biol Med 2007; 42: 706-719. [CrossRef]

16. Li L, Salto-Tellez M, Tan CH, Whiteman M, Moore PK. GYY4137, a novel hydrogen sulfide-releasing molecule, protects against endotoxic shock in the rat. Free Radic Biol Med 2009; 47: 103-113. [CrossRef]

17. Oh GS, Pae HO, Lee BS, Kim BN, Kim JM, Kim HR et al. Hydrogen sulfide inhibits nitric oxide production and nuclear factor- $\mathrm{KB}$ via heme oxygenase-1 expression in RAW264.7 macrophages stimulated with lipopolysaccharide. Free Radic Biol Med 2006; 41: 106119. [CrossRef]

18. Zhang $\mathrm{H}$, Zhi L, Moore PK, Bhatia M. Role of hydrogen sulfide in cecal ligation and puncture induced sepsis in the mouse. Am J Physiol Lung Cell Mol Physiol 2006; 290: 1193-1201. [CrossRef]

19. Zhang LM, Jiang CX, Liu DW. Hydrogen sulfide attenuates neuronal injury induced by vascular dementia via inhibiting apoptosis in rats. Neurochem Res 2009; 34: 1984-1992. [CrossRef]

20. Guan Q, Zhang Y, Yu C, Liu Y, Gao L, Zhao J. Hydrogen sulfide protects against high-glucose-induced apoptosis in endothelial cells. J Cardiovasc Pharmacol 2012; 59: 188-193. [CrossRef]

21. Lowry OH, Rosebrough NJ, Farr AL, Randall RJ. Protein measurement with the Folin phenol reagent. J. Biol. Chem. 1951; 193: 265275. 
22. Mihara M, Uchiyama M. Determination of malonaldehyde precursor in tissues by thiobarbituric acid test, Anal Biochem 1978; 86: 271-278. [CrossRef]

23. Bradley PP, Priebat DA, Christensen RD, Rothstein G. Measurement of cutaneous inflammation: estimation of neutrophil content with an enzyme marker, J Invest Dermatol. 1982; 78: 206209. [CrossRef]

24. Schmidt J, Rattner DW, Lewandrowski K, Compton CC, Mandavilli U, Knoefel WT, et al. A better model of acute pancreatitis for evaluating therapy. Ann Surg 1992; 215: 44-56. [CrossRef]

25. Moore PK, Bhatia M, Moochhala S. Hydrogen sulfide: from the smell of the past to the mediator of the future? Trends Pharmacol Sci 2003; 24: 609-611. [CrossRef]

26. Szabó $C$. Hydrogen sulphide and its therapeutic potential. Nat Rev Drug Discov 2007; 6: 917-935. [CrossRef]

27. Li, L, Bhatia M, Zhu YZ, Zhu YC, Ramnath RD, Wang ZJ, et al. Hydrogen sulfide is a novel mediator of lipopolysaccharide-induced inflammation in the mouse. FASEB J 2005; 19: 1196-1198. [CrossRef]

28. Wallace JL, Caliendo G, Santagada V, Cirino G, Fiorucci S. Gastrointestinal safety and anti-inflammatory effects of a hydrogen sulfide-releasing diclofenac derivative in the rat. Gastroenterology 2007; 132: 261-671. [CrossRef]

29. Sidhapuriwala JN, Ng SW, Bhatia M. Effects of hydrogen sulfide on inflammation in caerulein-induced acute pancreatitis. J Inflamm 2009; 6: 35. [CrossRef]

30. Banks PA, Tenner S, Noordhoek EC, Sica G, Feng S, Zinner M. Does pancreatic necrosis predict severity in-patients with acute necrotizing pancreatitis? Digestion 1996; 57: 218-223.

31. Bhatia M, Wong FL, Cao Y, Lau HY, Huang J, Puneet $P$, et al. Pathophysiology of acute pancreatitis. Pancreatology 2005; 5: 132-144. [CrossRef]
32. Sayek I., Turhan N. Pankreatit İskender Sayek ed. Temel Cerrahi Güneş Tıp Kitabevi 2013; 1691-1703.

33. Guercioni G, Siquini W, Senati E. Epidemiology, Classification, Etiopathogenesis and Diagnosis of Acute Pancreatitis. In: Siquini Walter (ed). Surgical Treatment of Pancreatic Diseases. Springer 2009; 31-63. [CrossRef]

34. Browne GW, Pitchumoni CS. Pathophysiology of pulmonary complications of acute pancreatitis. World J Gastroenterol 2006; 12: 7087-7096. [CrossRef]

35. Drent M, Cobben NA, Henderson RF, Jacobs JA, Wouters EF, van Dieijen-Visser MP. BAL fluid LDH activity and LDH isoenzyme pattern in lipoid pneumonia caused by an intravenous injection of lamp oil. Eur Respir J 1996; 9: 2416-2418. [CrossRef]

36. Drent $M$, Cobben NA, Henderson RF, Wouters EF, van Dieijen-Visser $M$. Usefulness of lactate dehydrogenase and its isoenzymes as indicators of lung damage or inflamation. Eur Respir J, 1996; 9: 1736-1742. [CrossRef]

37. Faller S, Zimmermann KK, Strosing KM, Engelstaedter $\mathrm{H}$, Buerkle $H$, Schmidt $R$, et al. Inhaled hydrogen sulfide protects against lipopolysaccharide-induced acute lung injury in mice. Med Gas Res 2012; 2: 26. [CrossRef]

38. George TJ, Arnaoutakis GJ, Beaty CA, Jandu SK, Santhanam L, Berkowitz $\mathrm{DE}$, et al. Hydrogen sulfide decreases reactive oxygen in a model of lung transplantation. J Surg Res 2012; 178: 494-501 [CrossRef]

39. Liu WL, Liu ZW, Li TS, Wang C, Zhao B. Hydrogen sulfide donor regulates alveolar epithelial cell apoptosis in rats with acute lung injury. Chin Med J. 2013; 126: 494-499. 